\title{
Notes
}

\section{Intra-Corporate Mail and Wire Fraud: Criminal Liability for Fiduciary Breach}

Mail/wire fraud law has evolved from its origins as an antidote to "lottery swindles" into a vehicle for attacking a wide range of conduct. Recently, a national standard of fiduciary liability, developed by federal courts in mail/wire fraud cases, has been held to govern the obligations of corporate directors and officers to their shareholders. ${ }^{1}$ Public, criminal enforcement under mail/wire fraud thus overlaps the private, civil enforcement of corporate fiduciary obligations. This Note contends that this use of the criminal law to police corporate fiduciary obligations is injurious to corporate shareholders-the supposed beneficiaries, contrary to principles of federalism that apply with special force in the corporate law context, and inconsistent with the principle that criminal proscriptions should be certain and knowable in advance.

This recent use of mail/wire fraud law to enforce fiduciary duties has little to do with fraud. The new corporate fiduciary standard is untenable on theoretical grounds, as is the use of criminal sanctions to enforce essentially contractual duties. Furthermore, this development in mail/wire fraud clashes with the congressional and judicial policy of minimizing federal involvement in intra-corporate affairs. The Note concludes that, contrary to accepted notions of legality, courts have used mail/wire fraud law to create a virtual common law crime.

1. See United States v. Weiss, No. 84-1103, slip op. (2d Cir. Jan. 7, 1985); United States v. Siegel, 717 F.2d 9 (2d Cir. 1983). Weiss and Siegel are mail/wire fraud cases premised upon an undisclosed breach of fiduciary duty by a corporate executive. Neither case suggests that any pecuniary injury befell shareholders. Rather, the cases assert that shareholders were deprived of the honest and faithful services of the defendant corporate officials and were thus "defrauded." Both cases involve the creation of a cash fund for a corporate employer-in Weiss by means of cash refunds on stock purchases and in Siegel by means of off-book sales of merchandise-which the defendants did not disclose to sharcholders. 


\section{Mail/Wire Fraud History and Development: From LOTTERY SWINDLeS to "CoRPorate IMPROPRIETIES"}

This section traces the development of mail/wire fraud law from its legislative origins to its current state.

\section{A. Legislative Origins and Early Development}

The federal mail fraud statute, ${ }^{2}$ enacted in 1870 to combat frauds perpetrated by lottery swindlers through the mails, ${ }^{3}$ long ago outgrew its origins. Serving as a jurisdictional hook to facilitate federal prosecutorial involvement where it is not otherwise explicitly authorized, the mail fraud statute is now regularly used to prosecute general wrongdoing on the basis that a letter was posted during the course of the scheme." Chief Justice Burger has described the statute as a "first line of defense"s against heretofore unseen criminal conduct against which prosecutors lack statutory weapons-indicating the expansive use to which the statute has been put. ${ }^{8}$

\section{18 U.S.C. $\S 1341$ (1982) provides, in pertinent part:}

Whoever, having devised or intending to devise any scheme or artifice to defraud, or for obtaining money or property by means of false or fraudulent pretenses, representations, or promises . . . places in any post office or authorized depository for mail matter, any matter or thing whatever to be sent or delivered by the Postal Service . . . shall be fined not more than

$\$ 1,000$ or imprisoned not more than five years, or both.

3. The bill's sponsor stated that the provision was necessary "to prevent the frauds which are mostly gotten up in the large cities . . . by thieves, forgers, and rapscallions generally, for the purpose of deceiving and fleecing the innocent people in the country." ConG. GLobe, 41st Cong., 3d Sess. 35 (1870) (remarks of Rep. Farnsworth).

4. For a discussion of the development of mail fraud, see Coffee, The Metastasis of Mail Fraud: The Continuing Story of the "Evolution" of a White-Collar Crime, 21 AM. CRIM. L. REv. 1 (1983) [hereinafter cited as Coffee, The Metastasis of Mail Fraud]; Coffee, From Tort to Crime: Some Reflections on the Criminalization of Fiduciary Breaches and the Problematic Line Between Law and Ethics, 19 AM. CRIM. L. Rev. 117 (1981); Hurson, Limiting the Federal Mail Fraud Statute-A Legislative Approach, 20 AM. CRIM. L. REV. 423, 426-35 (1983).

5. United States v. Maze, 414 U.S. 395, 405 (1974) (Burger, C.J., dissenting). The Chief Justice explained: "When a 'new' fraud develops-as constantly happens-the mail fraud statute becomes a stopgap device to deal on a temporary basis with the new phenomenon, until particularized legislation can be developed and passed to deal directly with the evil." Id. at 405-06.

Mail/wire fraud is used, however, as more than a stopgap device. These statutes have been used to prosecute conduct with which either state law or federal securities law has dealt for years. In fact, mail/wire fraud cases often involve securities law charges as well. See, e.g., United States v. Newman, 664 F.2d 12 (2d Cir. 1981) (involving mail fraud, and criminal violations of $\S 10$ (b) of Securities Exchange Act and SEC Rule 10b-5); United States v. Dixon, 536 F.2d 1388 (2d Cir. 1976) (involving mail fraud and numerous criminal violations of federal securities laws). Once mail/wire fraud has been stretched to cover heretofore unregulated conduct, even if legislation is passed to deal with the specific "evil," there is no guarantee that prosecutors will employ the new statutes rather than mail/ wire fraud. Expansive judicial interpretations of criminal statutes, made in the name of giving the legislature a chance to enact specific legislation, serve in fact to encourage prosecutors to stick with the old, general enabling statutes and allow them to prosecute conduct against which the legislature may never choose to pass a federal law. Furthermore, the existence of such open-ended statutes may lessen the incentive for the legislature to respond to a weakness in the law with appropriate legislation.

6. Jed Rakoff, a former federal prosecutor, in a blush of enthusiasm for the mail fraud statute's versatility, described the statute as follows:

To federal prosecutors of white collar crime, the mail fraud statute is our Stradivarius, our 
The elements of mail and wire fraud, ${ }^{7}$ as these statutes have recently been construed, ${ }^{8}$ consist of the formation of a scheme to defraud ${ }^{9}$ and use of the mails/wires to further the scheme. ${ }^{10}$

Under the "intangible-rights" doctrine, proof of fraud does not turn on whether a fiduciary acquired a victim's property under false pretenses; he is criminally liable if he deprived his beneficiaries of their right to honest and faithful services. ${ }^{11}$ Recent mail/wire fraud cases have extended this doctrine. ${ }^{12}$ To establish fraud, the prosecution need not prove that the

Colt 45, our Louisville Slugger, our Cuisinart-and our true love. We may flirt with RICO, show off with 10b-5, and call the conspiracy law "darling," but we always come home to the virtues of 18 U.S.C. $\$ 1341$, with its simplicity, adaptability, and comfortable familiarity. It understands us and, like many a foolish spouse, we like to think we understand it.

Rakoff, The Federal Mail Fraud Statute (pt. 1), 18 DuQ. L. REv. 771, 771 (1980) (citations omitted).

7. The federal wire fraud statute, 18 U.S.C. § 1343 (1982), provides:

Whoever, having devised or intending to devise any scheme or artifice to defraud, or for obtaining money or property by means of false or fraudulent pretenses, representations, or promises, transmits or causes to be transmitted by means of wire, radio, or television communication in interstate or foreign commerce, any writings, signs, signals, pictures, or sounds for the purpose of executing such scheme or artifice, shall be fined not more than $\$ 1,000$ or imprisoned not more than five years, or both.

8. The mail and wire fraud statutes have been identically construed with respect to the issues discussed herein. See Weiss, No. 84-1103, slip op. (2d Cir. Jan. 7, 1985) (relying on Siegel, a wire fraud case, to affirm mail fraud convictions); Siegel, 717 F.2d at 14; United States v. Barta, 635 F.2d 999, 1005 n.11 (2d Cir. 1980), cert. denied, 450 U.S. 998 (1981); United States v. Louderman, 576 F.2d 1383, 1387 n.3 (9th Cir.), cert. denied, 439 U.S. 896 (1978).

9. The question of what constitutes a scheme to defraud has long been elusive. Courts have at times relied on analogies to breaches of duty in other areas of law in order to define the term "fraud." For a discussion of the judicial treatment of the fraud requirement of the federal conspiracy statute, see Goldstein, Conspiracy to Defraud the United States, 68 YALE L.J. 405 (1959).

10. Use of the mails or of electronic means of communication serves as the basis of federal jurisdiction. The communications need not be fraudulent, but must simply be made in the course of the scheme. See United States v. Abrams, 539 F.Supp. 378, 383 (S.D.N.Y. 1982) ("To prove a violation of 18 U.S.C. $\S 1343$, the government must prove that the defendant was a knowing participant in a fraudulent scheme that was furthered by the use of interstate transmission facilities.") (citation omitted).

11. The intangible-rights doctrine has been used to prosecute political figures for corruption. See, e.g., United States v. Margiotta, 688 F.2d 108 (2d Cir. 1982), cert. denied, 461 U.S. 913 (1983); United States v. Mandel, 591 F.2d 1347 (4th Cir.), affd in relevant part on reh'g en banc, 602 F.2d 653 (4th Cir. 1979) (per curiam), cert. denied, 445 U.S. 961 (1980); United States v. Brown, 540 F.2d 364 (8th Cir. 1976); United States v. Keane, 522 F.2d 534 (7th Cir. 1975), cert. denied, 424 U.S. 976 (1976); United States v. Issacs, 493 F.2d 1124 (7th Cir.), cert. denied, 417 U.S. 976 (1974); United States v. States, 488 F.2d 761 (8th Cir. 1973), cert. denied, 417 U.S. 909 (1974). This use of the doctrine has been criticized. See Comment, The Intangible-Rights Doctrine and PoliticalCorruption Prosecutions Under the Federal Mail Fraud Statute, 47 U. CHI. L. REv. 562, 564 (1980) (mail fraud statute "should not be read to extend to political-corruption cases").

12. Recently, the intangible-rights doctrine has been used to prosecute private fiduciaries. See Weiss, No. 84-1103, slip op. at 7103 (2d Cir. Jan. 7, 1985); Siegel, 717 F.2d at 13. See also United States v. Newman, 664 F.2d 12 (2d Cir. 1981) (reinstating indictment on mail fraud charges of securities trader who participated in scheme to trade on information regarding corporate takeovers obtained from employees of investment banking firms); United States v. Bronston, 658 F.2d 920 (2d Cir. 1981) (affirming conviction of defendant, a partner in a law firm and a state senator, for mail fraud involving breach of fiduciary duty as an attorney and breach of duty of loyalty to the firm and one of its clients by promoting the interests of client's competitor), cert. denied, 456 U.S. 915 (1982); United States v. Barta, 635 F.2d 999 (2d Cir. 1980) (reinstating indictment of bond trader/salesman 
fraud's victims were directly harmed. ${ }^{13}$ Rather, the now-standard test ${ }^{14}$ requires both a breach of duty by a fiduciary and nondisclosure ${ }^{15}$ of material information. ${ }^{16}$ However, nondisclosure of the breach itself ${ }^{17}$ consti-

in especially powerful and trusted position for wire fraud and conspiracy based on allegations that he withheld information about thin capitalization of trading firm in which he had an interest). But see United States v. Dixon, 536 F.2d 1388 (2d Cir. 1976) (refusing to extend intangible-rights doctrine to private fiduciaries). Dixan has proven to be an abberation in the Second Circuit which has allowed use of the doctrine to prosecute private fiduciaries since Barta.

13. There is some doubt as to whether the prosecution is required to prove that harm was even contemplated. "The district court erred in holding that, in every mail fraud case based upon a breach of fiduciary duty by a private employee, there must be proof of 'direct, tangible, economic loss to the victim, actual or contemplated." Newman, 664 F.2d at 20 (citations omitted) (emphasis added). But see Siegel, 717 F.2d at 14 ("the prosecution must show that some harm or injury was contemplated by the scheme, United States v. Dixon, 536 F.2d 1388, 1399 n.11 (2d Cir, 1976)"). It is not clear that the Siegel court properly applied the existing law of the Second Circuit, since Barta seemed to overrule Dixon. However, Weiss, the most recent case, followed Siegel. "While the government must show that some harm or injury was contemplated by the scheme, it need not show that 'direct, tangible economic loss resulted to the scheme's intended victims." Weiss, No. 84-1103, slip op. at 7102-03 (2d Cir. Jan. 7, 1985) (citations omitted).

14. Formulated by the Seventh Circuit in United States v. Bush, 522 F.2d 641, 648 (7th Cir. 1975), cert. denied, 424 U.S. 977 (1976), this test has been widely followed in the circuits. See cases cited supra notes 11 \& 12.

15. "The additional element which frequently transforms a mere fiduciary breach into a criminal offense is a violation of the employee's duty to disclose material information to his employer." Barta, 635 F.2d at 1006.

16. Despite the refinement of the materiality standard in the context of the federal securities laws, mail/wire fraud cases do not refer to that standard. See TSC Industries, Inc. v. Northway, Inc., 426 U.S. 438, 449 (1976) (characterizing materiality for purposes of SEC Rule 14a-9, which prohibits false or misleading statements in proxy solicitations, as "[whether] there is a substantial likelihood that a reasonable shareholder would consider [an omitted fact] important in deciding how to vote. . . . Put another way, there must be a substantial likelihood that the disclosure of the omitted fact would have been viewed by the reasonable investor as having significantly altered the 'total mix' of information made available."). The mail/wire fraud standard of materiality, in contrast, has been drawn from whole cloth by judges on an ad hoc basis. See Siegel, 717 F.2d at 15 (quoting jury instruction which read, "a material fact is one which would be important to a reasonable person in deciding whether to engage in a particular transaction or to engage in certain conduct."). Defendants in Siegel alleged that the amount involved in their "scheme" ( $\$ 100,000$ over a nine-year period or slightly more than $\$ 11,000$ per year) was so small as to be immaterial in light of the corporation's sales volume, which ranged between $\$ 30$ million and $\$ 109$ million in the nine-year period. The majority dismissed this defense, claiming that it "borders on the frivolous." Siegel, 717 F.2d at 14. The dissent, however, is more consistent with $T S C$, characterizing the amount involved as "a wholly trivial sum in light of Mego's sales. In holding that these transactions 'would be important to a Mego stockholder,' the majority simply closes its eyes to investment realities, for there is not a shred of evidence that such a sum would affect share price in the slightest." Siegel, 717 F.2d at 24 (Winter, J., dissenting).

On the application of the TSC standard in cases involving illegal corporate activity, see Roiter, Illegal Corporate Practices and the Disclosure Requirements of the Federal Securities Laws, 50 FORDHAM L. REv. 781, 790 (1982) ("[T]he standard of financial materiality, based on the premise that monetary gain is the paramount, if not sole, concern of stockholders, must generally be met." (footnote omitted)).

17. The element of nondisclosure does little to narrow this standard of liability, since fiduciaries are unlikely to disclose their breaches of duty. See Coffee, The Metastasis of Mail Fraud, supra note 4, at 1-2 ("As a practical matter, the operative effect of this disclosure requirement is to simplify the prosecutor's case by substituting proof of nondisclosure for proof of loss or illicit gain.").

The majority in Siegel noted that under prior Second Circuit decisions,

"a mere breach of fiduciary duty, standing alone, may not necessarily constitute a mail fraud,"

....

However, we have held that the statute is violated when a fiduciary fails to disclose material 
tutes nondisclosure for the purposes of establishing "fraud." The conduct prohibited by these statutes is, therefore, nothing more than an undisclosed breach of duty by anyone labeled a fiduciary. ${ }^{18}$

\section{B. Elimination of the "Scheme to Defraud" Element: The Crime of "Corporate Improprieties"}

The law of fiduciary obligations, an age-old and highly articulated component of corporate law, ${ }^{10}$ has been loosely transposed into federal criminal law in mail/wire fraud cases. By defining the formation of a "scheme to defraud" by reference to a breach of fiduciary duty, and broadening the definition of such a breach to include non-injurious conduct, $^{20}$ recent cases seem to eliminate the last vestiges of the element of fraud from mail/wire fraud.

It is thus no longer clear that the prosecution must prove the existence of a scheme to defraud as one element of mail/wire fraud. United States v. Siegel ${ }^{21}$ and United States $v$. Weiss ${ }^{22}$ both involved wide-ranging allegations of criminal wrongdoing, but in both cases, the mail/wire fraud convictions were premised on defendants' creation of an unaccounted-for

information "which he is under a duty to disclose to another under circumstances where the non-disclosure could or does result in harm to the other."

Siegel, 717 F.2d at 14 (citations omitted). The court concluded that the jury could have found that the defendants acted "in breach of their fiduciary duties to act in the best interest of the corporation and to disclose material information." Id. (emphasis added). Disclosure itself is thereby a fiduciary duty; in failing to make adequate disclosure, the defendants breached their fiduciary duties. Therefore, no more than a "mere breach of fiduciary duty" is required to establish mail/wire fraud if the duty breached is the duty to disclose material information.

18. Fiduciary relationships are quite common. One commentator has noted that "our society is cvolving into one based predominantly on fiduciary relations." Frankel, Fiduciary Law, 71 CaLIF. L. REv. 795, 798 (1983). Fiduciary relationships are the subject of

a considerable body of law based on implied or express contract governing whether particular behavior is legal. Its most notable feature, however, is the degree to which fiduciary obligations vary from relationship to relationship. Partners, employees, trustees and corporate directors are all fiduciaries, yet their legal obligations may be wholly dissimilar. While an hourly employee usually may quit a job without fearing legal action even though he leaves at a time which makes it difficult for the employer to continue business, a trustee may not so easily abandon his beneficiaries. While a trustee's actions are void or voidable if tainted by a conflict of interest, the corporate officer generally can act even if he is personally interested so long as the action is fair to the corporation.

United States v. Margiotta, 688 F.2d 108, 142 (2d Cir. 1982) (Winter, J., dissenting), cert. denied, 461 U.S. 913 (1983). Yet, the reviewing courts in mail/wire fraud cases have not discussed the variety of fiduciary relationships, nor have they spoken of the various fiduciary duties. Instead, they have referred to "fiduciary duty" as if it were a unitary concept.

19. See W. Cary \& M. Eisenberg, Cases and Materials on Corporations 518-712 (5th ed. 1980).

20. See Weiss, No. 84-1103, slip op. at 7120 (2d Cir. Jan. 7, 1985) (Newman, J., dissenting) ("[C]reation of the cash fund, for which Weiss was convicted, was indisputably for the benefit of the corporation."). Similarly, in Siegel, the conduct for which the defendants were convicted benefited the corporation by providing it with cash.

21. 717 F.2d 9 (2d Cir. 1983).

22. No. 84-1103. slip op. (2d Cir. Jan. 7, 1985). 
pool of cash for their corporate employer. ${ }^{23}$ In neither case was there any direct evidence that the defendants used the cash for personal benefit. In Siegel, the majority used a judicial sleight-of-hand in order to allow the inference that the defendants used the money for self-enrichment. Specifically, it noted as probative of personal use the fact that "there was testimony which showed that [the defendants] personally received the proceeds from the cash sales and either pocketed them or placed them in the corporate safe deposit box."24 As the dissent in Siegel noted, however,

By allowing an inference of diversion to personal use to be drawn solely from the lack of proper records, the majority has in effect dropped the element of a scheme to defraud from the offense. . . . In effect, a new crime-corporate improprieties-which entails neither fraud nor even a victim, has been created. ${ }^{25}$

Weiss confirms the accuracy of this view of Siegel:

Our case is within the ambit of the holding in Siegel. There is no requirement that the government prove that the misappropriated funds were used by Weiss for his own enrichment. Rather, evidence of a non-corporate purpose, explicitly or implicitly derived, will satisfy the requirements of Siegel. ${ }^{26}$

Hence, it is sufficient for the government to prove only that corporate executives generated a pool of cash for the corporation ${ }^{27}$-an act which does not injure shareholders ${ }^{28}$-in order to establish a breach of fiduciary

23. Cash transactions are often the hallmark of tax evasion, and defendants in Siegel were in fact convicted of "aiding in the preparation of a false corporate income tax return in violation of 26 U.S.C. $\$ 7206(2)$." Siegel, 717 F.2d at 10. Neither defendant appealed. The defendant in Weiss, however, "was acquitted of . . . four counts of tax fraud, 26 U.S.C. \& 7206(2)." Weiss, No. 84-1103, slip op. at 7095 (2d Cir. Jan. 7, 1985).

24. Siegel, 717 F.2d at 15.

25. Siegel, 717 F.2d at 24 (Winter, J., dissenting).

26. Weiss, No. 84-1103, slip op. at 7104 (2d Cir. Jan. 7, 1985) (emphasis added). In fact, the prosecution in Weiss had alleged in the indictment that the defendant, and not the corporation, had kept the cash. At trial, however, the prosecution dropped this allegation and instead contended that Weiss defrauded shareholders by creating a cash fund for the corporation. This change drew a sharply worded dissent from Judge Newman on the grounds that it amounted to "an egregious example of a constructive amendment of an indictment, in violation of the Fifth Amendment." Id. at 7120 (Newman, J., dissenting).

27. There are suggestions in Siegel that the defendants used the cash to bribe labor officials and customers, and in Weiss that the defendant falsified documents, but in neither case was the government required to prove these allegations in order to make out a case of mail/wire fraud. Rather, the prosecution presented these allegations to the juries in order to support the claim that the defendants acted with a "non-corporate purpose" in mind. Had the prosecution in fact been able to prove these allegations, presumably they would have done so, and, to the extent that the conduct involved was in fact criminal (which is not immediately obvious, at least in the case of commercial bribes or refunds), the prosecution would not have had to rely on mail/wire fraud.

28. It is more plausible to argue that shareholders or creditors of another corporation were injured by the conduct in Weiss. Weiss obtained stock in Westchester Premier Theatre ("WPT") for his 
duty sufficient to win mail/wire fraud convictions. Under this standard, an irregularity in bookkeeping, ${ }^{29}$ or any other such "corporate impropriety," would allow the inference of a non-corporate purpose and hence criminal liability for the corporation's executives despite their complete lack of fraudulent intent or effect. Thus, Weiss and Siegel stretch the definition of fiduciary duty so far as effectively to cut the tie between the mail/wire fraud statutes and fraud.

\section{Fiduciary Law in the Modern Corporation}

In contrast to the mail/wire fraud cases' ungrounded use of fiduciary liability, corporate law scholarship lays out a conceptual framework of fiduciary law based on its economic function in the modern corporation. ${ }^{30}$ While the mail/wire fraud cases simply invoke the term "fiduciary" without delineating the basis of such a duty or the type of duty owed by the fiduciary, corporate law cases have focused on defining who is a fiduciary $^{31}$ and what duties such status should entail. ${ }^{32}$

employer, Warner Communications, Inc., at what amounted to half-price. Weiss, using Warner funds, paid face value for the WPT stock and Warner received half of the purchase price back in cash. On the face of it, this transaction would seem to defraud those who invested in or lent to WPT believing that Warner had paid full price for its WPT stock. To the extent that WPT listed the Warner stock purchases at face value rather than at the net amount, it misrepresented its capitalization to investors and lenders in a way that could have injured them. This is quite speculative, however, since the case makes no reference to any such scenario. Note, however, that if these investors and lenders were in fact defrauded, they were defrauded by WPT with Weiss having only an accessorial role. Furthermore, the prosecution's theory in Weiss would be unavailing since Weiss owed no fiduciary duty to WPT's lenders and investors.

29. This is especially troublesome since accounting standards are constantly in flux:

Accounting, like other social science disciplines and human activities, is largely a product of its environment. The environment of accounting consists of social-economic-political-legal conditions, restraints, and influences that vary from time to time. As a result, accounting objectives and practices are not the same today as they were in the past, because accounting theory has evolved to meet changing demands and influences.

D. Kieso \& J. Weygandt, Intermediate Accounting 4 (4th ed. 1983) (emphasis in original).

30. See Easterbrook \& Fischel, Corporate Control Transactions, 91 YALE L.J. 698, 700-03 (1982) [hereinafter cited as Easterbrook \& Fischel]; Winter, State Law, Shareholder Protection, and the Theory of the Corporation, 6 J. LEGal STUD. 251, 273-76 (1977); Wolfson, A Critique of Corporate Law, 34 U. Miami L. Rev. 959, 975 (1980).

31. A classic presentation of the question of who owes the corporation's shareholders a fiduciary duty is Perlman v. Feldman, 219 F.2d 173, 175-76 (2d Cir.), cert. denied, 349 U.S. 952 (1955), which involved the question of whether a controlling shareholder (who was also chairman of the board of directors and president of the corporation) could sell his controlling interest in the corporation to a third party at a premium above the market value of the shares. For a discussion of this case, see Easterbrook \& Fischel, supra note 30, at 716-18.

32. In his formulation of this problem, Justice Frankfurter wrote:

[T]o say that a man is a fiduciary only begins an analysis; it gives direction to further inquiry. To whom is he a fiduciary? What obligations does he owe as a fiduciary? In what respect has he failed to discharge these obligations? And what are the consequences of his deviation from duty?

SEC v. Chenery Corp., 318 U.S. 80, 85-86 (1943). 


\section{A. Fiduciary Law and Agency Theory}

Corporate law scholarship on fiduciary obligations is built on the cornerstone recognition that fiduciary rules in the corporate domain govern agency relations, and that these rules, as such, are contractual in nature. ${ }^{33}$ In the context of the modern corporation, directors and officers serve as agents who advance the interests of their principals-the corporation's shareholders. The potential divergence of interest between agent and principal creates agency costs. ${ }^{34}$ Early corporate law scholarship emphasized the injury shareholders might suffer as control of large corporations was separated from ownership. ${ }^{35}$ Recent scholarship, however, points out that this separation facilitates large accumulations of capital and productive capacity and enables firms to exploit economies of scale, thereby benefiting shareholders and their agents. ${ }^{36}$ This separation is not costless to shareholders, who incur agency costs as a result of their having corporate executives run the firm. These costs include the costs of transacting with agents ${ }^{37}$ and costs which arise from agents' opportunism or laziness. ${ }^{38}$ The benefits associated with the separation may-and to the extent that large public corporations compete successfully with proprietorships, do-outweigh the costs.

The law of fiduciary duty aims at minimizing the costs that result from agency relationships while maximizing the gains for which principals enter into agency contracts. Judicially enforced fiduciary rules should reflect the contractual obligations the parties would have arranged had they been able:

33. Easterbrook \& Fischel characterize agency relationships as follows:

An agency relationship is an agreement in which one or more persons (the principal) delegates authority to another person (the agent) to perform some service on the principal's behalf. The entire corporate structure is a web of agency relationships.... .

Delegation-including the "separation of ownership and control"-exists because both principal and agent share in the benefits of agency relationships. Nonetheless, the interests of agents may diverge from the interests of principals after the delegation has occurred.

Easterbrook \& Fischel, supra note 30 , at 700-01.

34. See Jensen \& Meckling, Theory of the Firm: Managerial Behavior, Agency Costs and Ownership Structure, 3 J. Fin. Econ. 305 (1976); Fama, Agency Problems and the Theory of the Firm, 88 J. Pol. Econ. 288 (1980); Smith \& Warner, On Financial Contracting: An Analysis of Bond Covenants, 7 J. Fin. ECON. 117 (1979).

35. See A. Berle \& G. Means, The Modern Corporatton and Private Property 116 (rev. ed. 1968) ("[W] individuals other than those in control, the interests of the latter are as likely as not to be at variance with those of ownership and . . . the controlling group is in a position to serve its own interests.").

36. See supra note 30 .

37. "The new institutional economics is preoccupied with the origins, incidence, and ramifications of transaction costs." Williamson, Transaction-Cost Eccnomics: The Governance of Contractual Relations, 22 J.L. \& Econ. 233, 233 (1979).

38. "[M]anagers will manage with an eye to increasing their own expected utility by maximizing future compensation including salary, job tenure, promotion prospects, informal perquisites, and opportunities for consuming leisure and other goods on the job." Kraakman, Corporate Liability Strategies and the Costs of Legal Controls, 93 YaLE L.J. 857, 863 (1984). 
Acting as a standard-form penalty clause in every agency contract, the elastic contours of the fiduciary principle reflect the difficulty that contracting parties have in anticipating when and how their interests may diverge.

Socially optimal fiduciary rules approximate the bargain that investors and agents would strike if they were able to dicker at no cost. Such rules preserve the gains resulting from the delegation of authority and the division of labor while limiting the ability of agents to further their own interests at the expense of investors. The existence of such "off-the-rack" rules reduces the costs of transacting and of enforcing restrictions on the agent's powers. ${ }^{38}$

Imposing fiduciary duties by means of legal rules, however, deters harmful conduct by agents only at a cost to shareholder-principals. ${ }^{40}$ Nonlegal constraints, such as market constraints, may be both more effective and less expensive to shareholders than legal rules. ${ }^{41}$ Legal rules affecting corporations should, therefore, reflect the existence of these nonlegal constraints on managerial conduct, and should operate principally in those zones in which markets systematically underdeter harmful conduct (or do not deter it at all). ${ }^{42}$ Corporate fiduciary law should reflect not simply the danger of misconduct by corporate executives, but also an evaluation of

39. Easterbrook \& Fischel, supra note 30 , at 702 . Wolfson articulated a similar view:

The purpose of the fiduciary principle is to compel directors and controlling shareholders to manage the enterprise fairly on behalf of all the owners rather than in the interest of the managers or only some of the shareholders. It is essentially a regulatory attempt to minimize the agency costs of separation of ownership and control.

Wolfson, supra note 30 , at 975 .

40. Responding to an article on the "laxity" of Delaware corporate law, Professor Winter noted: To say a legal system is marked by "laxity" implies a cost-benefit judgment about more stringent regulation but such rhetoric in the shareholder protection area is rarely accompanied by the analysis such judgments call for. In truth, a "lax" legal system is neither intuitively nor empirically inferior to a stringent one.

Winter, supra note 30, at 258 (responding to Cary, Federalism and Corporate Law: Reflections Upon Delaware, 83 YALE L.J. 663 (1974)). A broad body of legal scholarship has since examined various problems of corporate regulation with an eye to the cost-effectiveness of legal rules. See EcoNomics of CoRporation Law and Securities Regulation (R. Posner \& K. Scott eds. 1980) (excerpting principal works); Carlton \& Fischel, The Regulation of Insider Trading, 35 STAN. L. REv. 857 (1983); Easterbrook \& Fischel, Mandatory Disclosure and the Protection of Investors, 70 VA. L. REV. 669 (1984) [hereinafter cited as Easterbrook \& Fischel, Mandatory Disclosure]; Gilson \& Kraakman, The Mechanisms of Market Efficiency, 70 VA. L. REV. 549 (1984); Kraakman, supra note 38 .

41. Markets which constrain managers include the product and service markets, the capital markets, the market for managerial services, and the so-called "market for management control." See Easterbrook \& Fischel, supra note 30 , at 701; Winter, supra note 30 , at 262-66. The pioneering article on the market for management control as a constraint on managerial behavior is Manne, Mergers and the Market for Corporate Control, 73 J. Pol. Econ. 110 (1965).

42. "[Market] mechanisms may be inadequate to deal with one-time defalcations, when the agent concludes that the opportunities of the moment exceed any subsequent penalties in the employment market." Easterbrook \& Fischel, supra note 30 , at 701. 
the costs of such misconduct compared to the costs associated with the laws that prohibit it. ${ }^{43}$

\section{B. The Traditional Duties of Corporate Fiduciaries}

Traditionally, corporate law has recognized two primary fiduciary duties-a duty of care in managing the affairs of the corporation and a duty of loyalty to the corporation ${ }^{44}$-and has defined these duties in a way that is consistent with their economic function.

\section{The Duty of Care and the Business Judgment Rule}

The business judgment rule protects corporate managers from liability by shielding bona-fide business judgments from judicial second-guessing, ${ }^{45}$ and is thus consistent with the contractual view of corporate fiduciary duties and with the notion that legal constraints on agents impose costs on principals. Managers, by virtue of their large investment of human capital in one firm, are undiversified ${ }^{46}$ and therefore more risk-averse than shareholders, who can diversify their holdings and thereby reduce their exposure to risk. ${ }^{47}$ Even without the risk of liability for business failure, corporate managers may prove overly risk-averse from the perspective of diversified shareholders. The purpose of the business judgment rule is to avoid exacerbating this already excessive managerial risk-aversion by

43. This type of analysis parallels that done in G. Calabresi, The Costs of Accidents (1970), which examines both accident costs and avoidance costs under different liability systems.

44. See W. Cary \& M. Eisenberg, supra note 19, at 518-712.

45. The business judgment rule reflects the fact that risk-taking benefits shareholders generally, though it will at times produce losses and hence lawsuits. The purpose of the rule is to prevent courts from second-guessing business decisions rendered by businesspersons under high-pressure, competitive conditions. Under the business judgment rule, ordinary negligence in the conduct of the business is insufficient to establish liability. See Aronson v. Lewis, 473 A.2d 805, 812 (Del. 1984) ("IU]nder the business judgment rule director liability is predicated upon concepts of gross negligence." (footnote omitted) (emphasis added)); Sinclair Oil Corp. v. Levien, 280 A.2d 717, 720 (Del. 1971) ("A board of directors enjoys a presumption of sound business judgment, and its decisions will not be disturbed if they can be attributed to any rational business purpose. A court under such circumstances will not substitute its own notions of what is or is not sound business judgment."); Kamin v. American Express Co., 86 Misc.2d 809, 813, 383 N.Y.S.2d 807, 811 (N.Y. Sup. Ct.) ("It is not enough to allege, as plaintiffs do here, that the directors made an imprudent decision . . . More than imprudence or mistaken judgment must be shown."), affd mem., 54 A.D.2d 654, 387 N.Y.S.2d 993 (N.Y. App. Div. 1976). But see Smith v. Van Gorkom, No. 255, at 3 (Del. Jan. 29, 1985) (declining to apply the business judgment rule where board's decision "was not the product of an informed business judgment." (emphasis added)). While there is disagreement over exactly when and how the rule should be applied, there is general agreement over the need for and purpose of the rule.

46. "Unlike shareholders, managers are undiversified risk bearers who invest their services in only one firm at a time. Thus, they will tend to evaluate firm projects with a risk-averse bias unless they are paid to do otherwise." Kraakman, supra note 38 , at 864 .

47. For an explanation of the value of diversification as a method of lessening risk, see $R$. Brealey \& S. Myers, Principles of Corporate Finance 120 (1981) ("DD]iversification can almost halve the variability of returns . . . . Diversification works because prices of different stocks do not move exactly together."); W. KLein, Business Organization and Finance: Legal and ECONOMiC PRINCIPLes 147-58 (1980). 
preventing the imposition of liability on managers who take worthy business risks and lose. Thus, the rule mitigates the inherent conflict of interest between managers and shareholders over the risk level of the firm. ${ }^{48}$ This rule is appropriate since substantial risk-taking is what shareholders contract for in purchasing common stock.

\section{The Duty of Loyalty}

Duty of loyalty cases arise out of transactions in which a corporate executive may have interests not fully concurrent with those of shareholders. In potential conflict of interest situations, the business judgment rule does not apply. ${ }^{49}$ Virtually all management decisions, however, can be construed as self-interested, ${ }^{50}$ or at least as having an impact on manage-

48. Management's inherent risk-aversion creates agency costs. Managers may avoid volatile but potentially profitable projects, or seek to diversify at the firm level to reduce the firm's overall risk level. See Amihud \& Lev, Risk Reduction as a Managerial Motive for Conglomerate Mergers, 12 BELL J. ECON. 605, 605 (1981) ("[M]anagers, as opposed to investors, are hypothesized to engage in conglomerate mergers to decrease their largely undiversifiable 'employment risk' . . . "); Note, The Conflict Between Managers and Shareholders in Diversifying Acquisitions: A Portfolio Theory Approach, 88 YALE L.J. 1238, 1241-44 (1979) (contending that managers seek to diversify their firmspecific investment in their corporate employer by diversifying through either internal expansion into new product lines or acquisition of companies in businesses unrelated to that of employer). Diversification at the firm level can prove quite costly to shareholders. See Mason \& Goudzwaard, Performance of Conglomerate Firms: A Portfolio Approach, 31 J. Fin. 39 (1976) (concluding that randomly selected diversified portfolio of securities, i.e., diversification at shareholder level, out-performed conglomerate firms). Thus, firm-level diversification may occur when managers choose to increase the stability of their employment at the expense of shareholder welfare.

Firm-level diversification may, in some instances, benefit shareholders. See Williamson, The Modern Corporation: Origins, Evolution, Attributes, 19 J. EcoN. LrT. 1537 (1981) (noting that managers properly make diversifying acquisitions to replace capital rationing mechanism of public finance markets with internal mechanism which may be preferable due to greater level of information available to decision makers).

49. See Aronson v. Lewis, 473 A.2d 805, 812 (Del. 1984) (in order for business judgment rule to apply, "directors can neither appear on both sides of a transaction nor expect to derive any personal financial benefit from it in the sense of self-dealing, as opposed to a benefit which devolves upon the corporation or all stockholders generally." (citations omitted)). Rather, when the directors have a personal interest in a transaction, they are required to establish that the transaction is fair to the corporation. Thus, both the burden of proof and the standard of review are different in cases involving self-interested dealings. See Sinclair Oil Corp. v. Levien, 280 A.2d 717, 720 (Del. 1971) ("When the situation involves a parent and a subsidiary, with the parent controlling the transaction and fixing the terms, the test of intrinsic fairness, with its resulting shifting of the burden of proof, is applied." (citations omitted)).

50. One crucial business decision, how to compensate managers, is unavoidably laced with potential conflicts of interest. Management itself (or a committee of outside directors which it chooses) must decide how to allocate the firm's income among reinvestment, dividends, and personal salaries or bonuses. To conclude that every dollar management keeps is taken from the pockets of shareholders is to miss the "supply-side" point that managers are more likely to produce corporate income for shareholders if they stand to benefit themselves from doing so. See P. RoBerTs, The Supply-Srde REvolution (1984). Thus, managers can stay within the bounds of an appropriate duty of loyalty while extracting very large salaries and bonuses, as long as they also benefit shareholders. Defining the duty of loyalty in executive compensation cases becomes a problem of arbitrary line-drawing. Wolfson explains: "While the director's duty of loyalty is intended to place some restraint upon management indulging its self-interest at the expense of shareholders, the doctrine is notoriously difficult to apply in the area of compensation, since corporate law cannot simulate a 'just' compensation pack- 
ment's welfare. ${ }^{51}$ It is therefore difficult to identify particular acts as violating the duty of loyalty for which shareholders would bargain. Legal enforcement of this duty should be undertaken only with trepidation, for it risks imposing too onerous a standard (one beyond that which shareholders would choose to impose) on management and thus deterring beneficial transactions.

The strength and efficiency of market constraints on managerial misconduct, coupled with the potentially deleterious effect on shareholders that could result from courts' policing of loyalty (even in civil actions), have led at least one commentator to recommend that courts cease trying to police corporate fiduciaries' duty of loyalty, leaving such policing exclusively to the various markets. ${ }^{52}$ If judicial searching for the precise legal requirement of loyalty for which shareholders would bargain is worth undertaking, it should be done with caution. One appropriate use of the duty of loyalty is to protect shareholders from one-time raids on the corporate assets by their manager-agents. This sort of misconduct is not policed by markets since these actors typically exit the marketplace and thus are not subject to its discipline. ${ }^{53}$ However, it is easier to cite the ideal situation in which law can function effectively than to characterize events that have already occurred as falling on one side or the other of the fiduciary line. Such decision-making is fraught with the risk of error.

\section{G. Corporate Fiduciary Liability Under Mail/Wire Fraud}

The mail/wire fraud standard of corporate fiduciary liability does not reflect recent advancement in corporate law theory and practice. The standard is not well suited to enforce either the duty of care or the duty of loyalty.

A general criminal statute, enforced by juries in criminal prosecutions, is too blunt an instrument with which to engage in the precise linedrawing necessary to enforce an appropriate standard of fiduciary loyalty. Judicial policing of loyalty, if worthwhile at all, ought not be done in

age. Only the market can do that." Wolfson, supra note 30 , at 975 (footnote omitted).

Nevertheless, it is quite plausible that under current mail/wire fraud doctrine, the criminal law may be used to police the duty of loyalty in just this way. "It requires little imagination to foresee future application of the theory of this case to the use of corporate airplanes, the size of executive salaries, expense accounts, etc." Siegel, 717 F.2d at 24 (Winter, J, dissenting).

51. In deciding to make an acquisition, for example, management may intend to increase returns to shareholders or to diversify its own position. See Note, supra note 48, at 1244 ("investment decisions afford managers the opportunity for reducing the firm-specific risk to which they are subjected").

52. See Wolfson, supra note 30, at 994 ("It is likely that much of corporate law produces more harm than good and frequently interferes with the benefits that would flow from the competitive forces of the marketplace.").

53. See supra note 42 . 
criminal cases, where the consequences of the inevitable failures of judgment are severe.

In Siegel, wire fraud convictions were based on defendants' involvement in "a scheme to defraud [the corporation and its] stockholders by violating their fiduciary duties to act honestly and faithfully in the best interest of the corporation . . . ."154 Though this holding seems to have been directed at a breach of loyalty, by its own terms the holding can apply to general breaches of fiduciary duties, including a breach of the duty of care. Appropriate enforcement of the duty of care involves application of the business judgment rule, yet federal courts have applied no such rule to limit liability in mail/wire fraud cases. ${ }^{55}$ Under current mail/wire fraud law, then, ordinary business failure may yield criminal liability.

The heightened possibility of liability, indeed of criminal liability, for business failure or suspect loyalty is likely to magnify the already excessive risk-aversion of corporate managers ${ }^{58}$-or cause them to demand increased compensation to offset this risk of criminal liability-and thereby reduce returns to shareholders. To the detriment of the alleged victims of fraud-the shareholders-mail/wire fraud law circumvents a state law system of private, civil enforcement of fiduciary duties that is consistent with the economic function of corporate law. ${ }^{\mathbf{B}}$

\section{Siegel, 717 F.2d at 13.}

55. The court in Siegel could reasonably have inferred a business judgment rule from the "honest and faithful" language, but it did not; nor did the Weiss court in applying the holding in Siegel. Interestingly, the Siegel court acknowledged the weak foundation of the prosecution's case:

In affirming defendants' convictions on the wire fraud counts, we in no way wish to encourage the type of indictment prosecuted here. Twenty counts were brought against five defendants, all but two of whom were acquitted of all charges. Siegel and Abrams, although convicted of the wire fraud charges (which might more properly have been redressed in a shareholder's derivative suit or in a state criminal prosecution), were acquitted on several other counts. . . .

[We] urge the government to think carefully before instituting other massive prosecutions having such slender foundations as this one.

Siegel, 717 F.2d at 22-23 (emphasis added). Despite the court's admonition, the U.S. Attorney's office in the Southern District of New York argued-successfully-the precise terms of Siegel in Weiss.

56. See supra note 46. Arthur Liman, a prominent member of the New York bar, noted, "To the businessman ... prison is the inferno, and conventional risk-reward analysis breaks down when the risk is jail." Liman, The Paper Label Sentences: Critiques, 86 YALE L.J. 619, 630-31 (1977). The risk of jail for affluent white-collar defendants is not purely hypothetical. See Wheeler, Weisburd \& Bode, Sentencing the White-Collar Offender: Rhetoric and Reality, 47 AM. Soc. Rev. 641, 658 (1982) (empirical study of white-collar sentencing revealed "a consistent and strong positive relationship between socioeconomic status and the severity of the sentence, thus requiring modification of most currently held views regarding that relationship.").

57. In addition, the current standard of liability under mail/wire fraud produces a dangerous anomaly -a standard of criminal liability more expansive than the corresponding standard of civil liability, notwithstanding the higher burden of proof required in criminal cases. In turn, private litigants may be able to use the criminal standard to expand the civil standard, thus compounding the problems caused by the criminal standard. On the use of criminal convictions to support civil damages, see RESTATEMENT (SECOND) OF JUDGMENTS $§ 85$ (1980).

Civil damages may also result under the Racketeer Influenced and Corrupt Organizations Act ("RICO"), 18 U.S.C. $\S 1964$ (1982). In Weiss, three counts of mail fraud served as the predicate felonies for a RICO count under which the defendant was forced to disgorge stock and warrants 


\section{Fiduciary Rules and the Criminal Law}

Fiduciary rules aim at approximating after the fact the standard of conduct for which the contracting parties would have bargained could they have done so cheaply. The very reason for the existence of fiduciary rules-the inability of the parties to spell out in advance precisely what sort of conduct will be prohibited-suggests that these rules should not be enforced with criminal sanctions. Even if courts are able to predict ex post what the parties would have bargained for $e x$ ante, it is difficult to justify enforcing this judicially constructed implied contract with the criminal law. The parties neither would nor could have contracted for criminal sanctions as the enforcement provision of their contract. Hence, this use of mail/wire fraud fails to approximate the will of the parties and is thus bad contract law. It is bad criminal law as well. By definition, fiduciary rules involve ex post judicial predictions of what the parties would have required. The content of criminal laws, in contrast, should be knowable in advance. $^{\mathrm{ss}}$

\section{The Practical Impact of Expansive Mail/Wire Fraud}

The problem of unwarranted prosecution of corporate executives is not simply academic. Even a small number of convictions in this area significantly and adversely affects the law of corporate fiduciary obligations and hence the welfare of agents and principals. The overly expansive standard of criminal liability arms federal prosecutors with the means to prosecute and convict for a broad range of conduct without requiring them to surmount specific evidentiary hurdles and prove the type of elements traditionally necessary for criminal convictions. When short-cut criminal statutes exist, prosecutors use them.

Prosecutors make extensive use of mail/wire fraud for several reasons. Mail/wire fraud charges can be effective prosecution bargaining chips in the plea negotiation process. ${ }^{69}$ Given these statutes' flexibility, prosecutors

worth approximately \$412,000. See Weiss, No. 84-1103, slip op. at 7095 (2d Cir. Jan. 7, 1985).

58. Liman bemoaned the proliferation of ex post facto criminal law:

It once was a first principle of our law that no one could be tried for a crime unless the offense had been defined by the legislature in advance with sufficient clarity to warn the offender of the consequences of his conduct. But today laws and regulations to which criminal sanctions have been tacked are often so vague and complex that the verdict, ex post facto, defines the crime.

Liman, supra note 56, at 634. See also Goldstein, supra note 9, at 463 (characterizing conspiracy to defraud the United States as "a Kafkaesque crime, unknown and unknowable except in terms of the facts of each case-and even then, not until the verdict has been handed down.").

59. See generally 13 LAw \& Soc'Y REv. 189 (1979) (special issue on plea bargaining); Katz, Legality and Equality: Plea Bargaining in the Prosecution of White-Collar and Common Crimes, 13 LAw \& Soc'y REv. 431 (1979). In one study of white-collar crime, 82\% of white-collar convictions resulted from guilty pleas. Wheeler, Weisburd \& Bode, supra note 56, at 643 . For an excellent 
can add mail/wire fraud counts to a wide variety of indictments, aiming to exchange dropped charges for guilty pleas and/or evidence to be used against other defendants. This effect is largely invisible since no judicial opinions result from plea deals. Therefore, it is hard to know, but perhaps easy to speculate, just how strong a "stick" the threat of mail/wire fraud prosecutions is to potential defendants. Given the experienced and expert nature of the white-collar defense bar, ${ }^{60}$ it is likely that the mail/wire fraud statutes are indeed effective bargaining tools. ${ }^{61}$ Hence, many illgotten plea deals probably result from threatened mail/wire fraud prosecutions.

The white-collar crime investigatory process, described by a former prosecutor as follows, also encourages prosecutors to rely on mail/wire fraud:

Since the ultimate object of any investigation is indictment and either plea or trial, federal prosecutors frequently will bring a case relatively unrelated to whatever they originally were pursuing, simply because it is an indictable, triable case. The federal agents who work under the prosecutors also are anxious to turn investigations into actual prosecutions. They may press the prosecutor for indictment of whatever offenses appear to be indictable, even if those offenses have little relation to the initial investigation or involve lesser targets or less serious conduct than originally anticipated. ${ }^{62}$

Moreover, the open-ended elements of mail/wire fraud tempt prosecu-

discussion of the importance of the plea bargaining process in the white-collar crime context, see $K$. Mann, Defending White-Collar CRIme: A Portrait of AtTorneys at Work 19-24 (forthcoming 1985) [hereinafter cited, in draft form, as K. MANN].

60. Mann explains that the white-collar defense bar centers around a small (but growing) circle of New York attorneys, many of whom learned their trade as prosecutors:

The continued high priority given to white collar crime investigations and prosecutions in the Southern District of New York and the high standard of practice maintained in that office created a cadre of skilled young attorneys who could become defense practitioners after training in handling white collar cases from the prosecution side. Thus, not only has the prosecution policy of the district created a pool of clients, but also a pool of attorneys who could meet the new demand for legal services in the private sector.

K. MaNN, supra note 59, at 33. The fact that both Siegel and Weiss are Second Circuit cases takes on added importance given both the focus of the white-collar criminal defense bar on and the concentration of financial activity in that circuit.

61. Mann explains: "Essential to defense planning is knowing whether the government will be able to prove a crime against the client . . . Id. at 22. Given the open-ended standard of criminal liability under mail/wire fraud and the consequent ease with which the prosecution can win a conviction, prudent defense counsel will opt to bargain early.

62. Hurson, supra note 4 , at 433 (footnote omitted). The author continues:

By the time this process reaches the indictment stage, agents and prosecutors may find themselves with facts accumulated through the course of their investigation that amount to some sort of improper or dishonest activity but do not fit the traditional criteria for a federal offense. . . Quite often mail fraud is the only federal criminal charge available to bring against a private individual or a nonfederal public official involved in corrupt activity.

Id. at 433-34 (footnote omitted). 
tors to charge mail/wire fraud in lieu of the more difficult (and more costly) to prove offense actually involved.$^{63}$ Finally, prosecutors add mail/ wire fraud counts as insurance when the primary charges rest on unsure evidentiary footing. ${ }^{64}$ If the primary counts are weakened during the course of the trial, the prosecutor can fall back on easy-to-prove mail/wire fraud as a face-saving device. ${ }^{68}$

\section{Federalism and the Development of Beneficial GORPORATE LAW}

The recent trend in mail/wire fraud cases suggests that federal prosecutors may soon lead the federal government into policing the internal affairs of corporations by nationalizing (and criminalizing) the law of corporate fiduciary obligations. This development is flatly inconsistent with both Congress' refusal to nationalize corporate law by means of national chartering of corporations and the federal courts' refusal to do so through interpretation of the federal securities laws. Despite this clear legislative and judicial preference in the corporate and securities law context, federal prosecutors threaten to work an "end-run" of a beneficial system of state corporate law by means of mail/wire fraud.

\section{A. The Value of the Traditional Federal/State Split in Corporate Regulation}

Congress has entrusted substantive regulation of intra-corporate affairs to the states. ${ }^{68}$ Federal corporate law has traditionally been limited to a mandatory disclosure system governing the sale and exchange of securities. ${ }^{67}$ One value of federalism-that the states may serve as laboratories

63. For this reason, mail/wire fraud opinions often read as if they involved violations of other provisions. See supra note 27. Prosecutors hoping to establish criminal liability "on the cheap" may be frustrated even when employing the mail/wire fraud statutes. See Siegel, 717 F.2d at 25 (Winter, J., dissenting) (unfavorably comparing benefits of wire fraud prosecutions to costs of lengthy trial).

64. See Hurson, supra note 4 , at 435 ("[I]t has become standard practice for federal prosecutors to tack on mail fraud charges as insurance' counts, even when the facts of a case call for application of a different federal criminal statute." (citation omitted)).

65. Siegel reads as if it were a bribery or theft case, but apparently neither of these offenses could be proven. See supra note 27.

66. See Cort v. Ash, 422 U.S. 66, 84 (1975).

67. The Supreme Court has characterized the purpose of the federal securities laws as substituting "a philosophy of full disclosure for the philosophy of caveat emptor." SEC v. Capital Gains Research Bureau, 375 U.S. 180, 186 (1963). The question of whether the SEC disclosure regime benefits shareholders is controversial. See S. Phillips \& J. Zecher, The SEC and the Public INTEREST (1981) (concluding that SEC disclosure regime does not benefit investors); H. KRIPKE, The SEC and Corporate Disclosure: Regulation in Search of a Purpose (1979) (same); Benston, Required Disclosure and the Stock Market: An Evaluation of the Securities Exchange Act of 1934, 63 AM. Econ. REv. 132 (1973) (same); Seligman, The Historical Need for a Mandatory Corporate Disclosure System, 9 J. CoRP. L. 1 (1983) (concluding that SEG regime benefits investors); Easterbrook \& Fischel, Mandatory Disclosure, supra note 40 (expressing a middle view). 
for change in the law ${ }^{68}$-is especially prevalent in corporate law, where states traditionally have competed for corporate charters. ${ }^{69}$ To attract corporations, states must provide laws which minimize the cost of capital to firms by providing beneficial legal rules. The development of a standard of fiduciary liability which lowers firms' cost of capital ${ }^{\mathbf{7 0}}$ is a key factor in this interstate competition. States that adopt fiduciary standards which closely approximate the standard for which shareholders would bargain will be rewarded with additional chartering fees. ${ }^{71}$ Federal law, unlike state law, is not subject to a market discipline since corporations wishing to continue doing business in the United States cannot opt out of the jurisdiction. ${ }^{72}$ Hence, the very fact that mail/wire fraud law is federal law and, as such, not self-correcting in the way that state corporate law is suggests that mail/wire fraud law is an inappropriate tool for regulating the behavior of corporate fiduciaries.

\section{B. Congressional and Judicial Approval of Interstate Competition in Corporate Law}

Both Congress and the Supreme Court have made clear their unwillingness to nationalize corporate law. Proposals to institute national char-

68. See New State Ice Co. v. Liebmann, 285 U.S. 262, 311 (1932) (Brandeis, J. dissenting) ("It is one of the happy incidents of the federal system that a single courageous State may, if its citizens choose, serve as a laboratory; and try novel social and economic experiments without risk to the rest of the country."). For a discussion of the current implications of Brandeis' view, see Steiner, A Progressive Creed: The Experimental Federalism of Justice Brandeis, 2 YALE L. \& PoL'y REv. 1 (1983).

69. The original exposition of this view is Winter, supra note 30 , which examined "the rather venerable proposals calling for the federal regulation of the governance of corporations against an economic theory of corporate function and control," id. at 251 (footnote omitted) and concluded that "(1) Contrary to the conventional wisdom, competitive legal systems should tend toward optimality so far as the shareholder's relationship to the corporation is concerned. (2) State corporation codes in fact seem quite consistent (optimality, of course, is not provable) with what economic theory suggests are optimal legal arrangements." Id. at 254.

For a recent discussion of this issue, see R. Romano, Some Pieces of the Incorporation Puzzle (Nov. 1984) (draft manuscript, forthcoming in 1 J.L. EcoN. \& ORG. (1985)).

70. "Corporations must attract capital from a vast range of competing opportunities and the state which 'rigs' its code to benefit management will drive debt and equity capital away." Winter, supra note 30 , at 289 .

71. "The relation between state revenues and responsiveness is one feature that serves to bind a state to act cooperatively with firms by continuing to revise its code and thereby adequately service its corporate clientele." R. Romano, supra note 69, at 88. See also Winter, supra note 30, at 258-62.

This theory has been supported by empirical studies. See R. Romano, supra note 69, at 90 (concluding that "a centralized system could impose a welfare loss on firms"); Dodd \& Leftwich, The Market for Corporate Charters: "Unhealthy Competition" versus Federal Regulation, 53 J. Bus. 259,282 (1980) ("Our study reveals that the case for federal chartering is not supported by the evidence. The evidence is consistent with our hypothesis that managers of a firm take advantage of the competition among states to locate in a state which offers an efficient set of restrictions on the firm ....").

72. "[G]iven the size of the federal budget, there is no revenue incentive to constrain the national government from acting opportunistically by installing high franchise fees without delivering valuemaximizing laws, and there are no options for firms (except to become unincorporated) in retaliation against such behavior." R. Romano, supra note 69 , at 90 . 
tering of corporations were advanced and debated in the mid-1970's. ${ }^{73}$ Recognizing the virtue of the competition among states in corporate law, Congress rejected these proposals. Opponents of national chartering relied on the federalism argument during debate. ${ }^{74}$

The federal courts have also rejected efforts to nationalize corporate law. In Santa $\mathrm{Fe}$ Industries $v$. Green, ${ }^{75}$ the Supreme Court explicitly rejected the contention that section 10(b) of the Securities Exchange Act ${ }^{78}$ or SEC Rule $10 \mathrm{~b}-5,{ }^{77}$ federal provisions which regulate insider trading, also created a general federal law of fiduciary duties, stating: "Absent a clear indication of congressional intent, we are reluctant to federalize the substantial portion of the law of corporations that deals with transactions in securities, particularly where established state policies of corporate regulation would be overridden."

In litigation involving management defense against hostile tender offers, ${ }^{79}$ federal courts have also rejected attempts to expand the scope of federal corporate law. Claiming that they are injured when management employs certain defensive tactics to oppose tender offers, shareholders have challenged management's use of these tactics ${ }^{80}$ under section 14(e) of the Securities Exchange Act ${ }^{81}$ which prohibits fraud and manipulation in the tender offer process. The majority of federal courts which have heard such claims have, however, refused to read section 14(e), a federal disclosure

73. Proposals for national chartering are found in R. NADER, M. GREEN \& J. SELIGMAN, CoNstitutionalizing the Corporation: The Case for the Federal Ghartering of Giant Corporations (1976); Cary, supra note 40.

74. See Corporate Rights and Responsibilities, 1976: Hearings Before the Senate Comm. on Commerce, 94th Cong., 2d Sess. (1976). Compare statements of Charles Crompton, Jr., partner, Potter, Anderson \& Corroon, Wilmington, Del.; Henry G. Manne, Prof., Univ of Miami School of Law; John W. Riehm, Chamber of Commerce of the United States; and Ralph K. Winter, Jr., Prof., Yale University (defending system of state regulation) with statements of Ralph Nader, Mark J. Green, \& Joel Seligman, Corporate Accountability Research Group; Donald Schwartz, Prof., Georgetown Univ. Law Center (advocating federal chartering).

75. 430 U.S. 462 (1977).

76. 15 U.S.C. $\$ 78$ j (1982) prohibits manipulation or deception in connection with the purchase or sale of securities.

77. 17 CFR $\S 240.10 \mathrm{~b}-5$ (1982) prohibits fraud, false statements, and material omissions in connection with the purchase or sale of securities.

78. 430 U.S. at 479. The Court recalled its ruling in Cort v. Ash, 422 U.S. 66, 84 (1975) ("Corporations are creatures of state law, and investors commit their funds to corporate directors on the understanding that, except where federal law expressly requires certain responsibilities of directors with respect to stockholders, state law will govern the internal affairs of the corporation.").

79. For a discussion of the tender offer process, see Easterbrook \& Fischel, The Proper Role of a Target's Management in Responding to a Tender Offer, 94 HaRv. L. Rev. 1161 (1981).

80. See Data Probe Acquisition Corp. v. Datatab, Inc., 722 F.2d 1 (2d Cir. 1983), cert. denied, 104 S. Ct. 1326 (1984); Buffalo Forge Co. v. Ogden Corp., 717 F.2d 757 (2d Cir.), cert. denied, 104 S. Ct. 550 (1983); Billard v. Rockwell Intern. Corp., 683 F.2d 51 (2d Cir. 1982); Panter v. Marshall Field \& Co., 646 F.2d 271 (7th Cir.), cert. denied, 454 U.S. 1092 (1981) (cases rejecting § 14(e) claims in light of Santa Fe). But see Mobil Corp. v. Marathon Oil Co., 669 F.2d 366 (6th Cir. 1981) (allowing $\$ 14(e)$ challenge to defensive tactics in hostile tender offer).

81. 15 U.S.C. $\$ 78 \mathrm{n}$ (e) (1982). 
provision, as imposing a duty of passivity on target managers. ${ }^{82}$ Some of these tactics may indeed constitute breaches of an appropriate duty of care or loyalty. Because they are fully disclosed, however, and therefore not fraudulent or manipulative, they do not fall within the ambit of section 14(e) ${ }^{83}$ By maintaining the separation of tasks between state and federal law, the courts facilitate state law experimentation with solutions to complex legal and economic problems. ${ }^{84}$ Ultimately, the "market for law," wherein states compete for corporations' loyalties and charter fees, should create incentives for states to allow the optimal level of defense by target managers. ${ }^{85}$

82. See cases cited supra note 80. Even Judge Winter of the Second Circuit, despite his recognition of the importance of the integrity of the tender offer market, see Winter, supra note 30, at $270-73,287-89$, concluded in a $\$ 14(\mathrm{e})$ case that, "The gravamen of the claim advanced here is a breach of management's fiduciary duty to shareholders, a matter traditionally committed to state law, which, if entertained, would unquestionably embark us on a course leading to a federal common law of fiduciary obligations." Data Probe Acquisition Corp. v. Datatab, Inc., 722 F.2d 1, 4 (2d Cir. 1983), cert. denied, 104 S. Ct. 1326 (1984).

The lone dissenting circuit is the Sixth. See Mobil Corp. v. Marathon Oil Co., 669 F.2d 366 (6th Cir. 1981). That case arose out of an acquisition contest for Marathon. Mobil sued to enjoin the excrcise of "lock-up" options granted by Marathon to its favored potential acquirer, claiming that these options were manipulative and, therefore, violated $\$ 14(\mathrm{e})$. The Sixth Circuit, reversing the district court, ruled in favor of Mobil's request for a preliminary injunction. The decision reflected the court's disapproval of this defensive tactic, but may have had little impact on the parties involved in the bidding contest because an antitrust action had effectively precluded Mobil from acquiring Marathon. See Marathon Oil Co. v. Mobil Corp., 669 F.2d 378 (6th Cir. 1981), cert. denied, 455 U.S. 982 (1982). Cf. G. Calabresi, A Common Law For the Age of Statutes 34-35 (1982) (Justice Frankfurter's harsh construction of FELA and Jones Act in dissents amounted to "judicial blackmail" and was aimed at the legislature and not at substance of cases involved).

On the implications of corporate takeovers on shareholder welfare, see Bebchuk, The Case for Facilitating Competing Tender Offers: A Reply and Extension, 35 STAN. L. REv. 23 (1982); Easterbrook \& Fischel, Auctions and Sunk Costs in Tender Offers, 35 STAN. L. REv. 1 (1982); Gilson, Seeking Competitive Bids Versus Pure Passivity in Tender Offer Defense, 35 Stan. L. Rev. 51 (1982).

83. See Buffalo Forge Co. v. Ogden Corp, 717 F.2d 757, 760 (2d Cir.) ("An essential ingredient of a section 14(e) cause of action . . . is misrepresentation, i.e., the omission or misstatement of material facts.") (citations omitted)), cert. denied, 104 S. Ct. 550 (1983).

84. The Seventh Circuit actually heard and rejected state fiduciary law claims in Panter v. Marshall Field \& Co., 646 F.2d 271, 293-99 (7th Cir.), cert. denied, 454 U.S. 1092 (1981). The plaintiff's quite plausible state law claims would perhaps succeed under the laws of a state seeking to attract corporate charters.

85. Optimality in this context is difficult to establish. Target management's ability to defend against a hostile acquisition can be viewed as a form of compensation. If all defensive tactics were illegal (assuming that one could even identify all conduct aimed at resisting a hostile offer), managers would demand additional compensation for their services to public companies. Golden parachutes provide a useful analogy. When fashioned before the advent of a hostile acquisition attempt, they may reflect an effort to compensate managers for their risk of being dislodged. See Note, Golden Parachutes and the Business Judgment Rule: Toward a Proper Standard of Review, 94 YALE L.J. 909 (1985). Defensive tactics generally, however, are extremely costly to shareholders. See R. GiLson, Legal and Financial Materials on CoRporate AcQuisitions ch. 14 (forthcoming 1985) (cited in draft form). 


\section{ConCLUSION}

Mail/wire fraud convictions premised on a corporate executive's breach of fiduciary duty do not protect and may in fact injure shareholders. Such convictions have created ill-defined federal duties; duties which are better defined at the state level. These convictions can be defended on shareholder protection grounds only by ignoring the cost side of the analysis. The cases establish legal standards that prosecutors can exploit in procuring unwarranted convictions and guilty pleas.

The effective elimination of the element of fraud from mail/wire fraud $^{86}$ suggests that the purpose of these cases may not have been the protection of "defrauded victims." Although the case law speaks of breach of fiduciary duty to shareholders, ${ }^{87}$ prosecutors and judges might defend these cases as protecting society from corporate fiduciary misconduct. However, since this "misconduct" need not amount to fraud, it is left to judges and juries in future cases to spell out precisely what sort of conduct constitutes mail/wire fraud. This use of the mail/wire fraud statutes shifts responsibility for defining the limits of corporate fiduciary behavior from the legislature to prosecutors, judges, and juries and, in so doing, creates something akin to a common law crime ${ }^{88}$ offensive to accepted notions of legality.

Peter R. Ezersky

86. See supra text accompanying notes 19-29.

87. See Weiss, 84-1103, slip op. (2d Cir. Jan. 7, 1985); Siegel, 717 F.2d 9 (2d Cir. 1983).

88. See J. Hali, General Principles of Criminal law 27-69 (2d ed. 1960). 